\title{
Effects of Bromocriptine Administration to Pregnant Rabbits upon Fetal Lung Maturation
}

\author{
GUSTAVO A. GIUSSI, ${ }^{(26)}$ GUSTAVO BALLEJO, RAÚl BUSTOS, AND \\ ROBERTO CALDEYRO-BARCIA \\ Latin American Center of Perinatology and Human Development, Pan American Health Organization/World Health \\ Organization, Montevideo, Uruguay
}

\begin{abstract}
Summary
If endogenous prolactin secretion is important in normal development of fetal lung surfactant, the inhibition of its secretion should be associated with delayed maturation of fetal lung.

We therefore studied the effect of bromoergocriptine administration to pregnant rabbits upon lecithin content of fetal lung washes.

The does were treated since the 27 th day of gestation with either Mesilate of 2-Bromo- $\alpha$-ergocriptine $\left(\mathrm{C}_{32} \mathrm{H}_{40} \mathrm{BrN}_{5} \mathrm{O}_{5}\right.$, $\mathrm{CH}_{3} \mathrm{SO}_{3} \mathrm{H}$ ) (Bromocriptine) (Parlodel, Sandoz) (1 mg/kg/day) or solvent twice daily until delivery.

The newborns were killed immediately by intraperitoneal administration of sodium penthobarbital and tracheostomized; then lung washes were performed.

The extracted lipids were plated and run on heat-activated thin layers of silica gel $\mathrm{H}$. Lecithin was eluted, and phosphorus determination was performed.

The level of lecithin phosphorus in the lung washes of the fetuses whose mothers received Bromocriptine was $\bar{X}=2.24 \pm 0.39 \mu \mathrm{g} / \mathrm{g}$ dry lung weight, whereas that of fetuses of control does was $\overline{\mathrm{X}}=$ $6.93 \pm 2.64 \mu \mathrm{g} / \mathrm{g}$ dry lung weight $(P<0.001)$.

The mean body weight of the fetuses from treated mothers was $38.22 \pm 6.39 \mathrm{~g}$ whereas that of fetuses from control rabbits was $47.63 \pm 6.94 \mathrm{~g}(P<0.001)$.

The mother's body weight gain from days 26 to 30 in Bromocriptine-treated rabbits was $156.11 \pm 99.4 \mathrm{~g}$, whereas that of controls was $374.38 \pm 166.21 \mathrm{~g}(P<0.01)$.

\section{Speculation}

Prolactin could be involved in the normal biochemical development of the lung and also be necessary for a normal weight gain of mother and fetuses during the last stage of gestation.
\end{abstract}

Biochemical maturation of the fetal lung as revealed by an increase in lecithin production occurs towards the end of gestation.

This process is influenced by the administration of hormones such as glucocorticoids $(7,8)$, thyroxine (24), estrogens (16), and prolactin (14). Also, it has been shown that insulin (19), epidermal growth factor (4), $\beta$-adrenergic agents (25), and cholinergic drugs (5) could affect lung maturation.

Recently, it has been shown that there is a relationship between cord prolactin levels and respiratory distress syndrome incidence (e.g., low cord prolactin is associated with high incidence of this syndrome) $(11,12,15,21,22)$. This observation would suggest that endogenous prolactin could be involved in the process of lung maturation.

In this study, we postulated that if endogenous prolactin secretion is important in normal development of fetal lung surfactant, the inhibition of its secretion should be associated with delayed maturation of fetal lung.

We therefore studied the effect of bromoergocriptine adminis- tration to pregnant rabbits upon lecithin content of fetal lung washes.

\section{MATERIALS AND METHODS}

Time dated pregnant Californian rabbits (eight controls and nine bromocriptine treated) were used in this study.

They were mated between $10 \mathrm{AM}$ and $2 \mathrm{PM}$, and this day was taken as day 0 of gestation. The rabbits were fed ad libitum with water and rabbit food.

The does were treated since the 27 th day of gestation with either Bromocriptine (Parlodel, Sandoz) ( $1 \mathrm{mg} / \mathrm{kg} /$ day) or solvent twice daily until delivery. Delivery was performed by hysterotomy on day 30 of gestation.

The newborns were killed immediately by intraperitoneal administration of sodium penthobarbital before amniotic sac rupture and weighed. They were exsanguinated by cutting the abdominal aorta, and tracheotomy was performed in five of them. Once tracheostomized, lung washes were performed as previously described (3).

Briefly, each pair of lungs was gently lavaged with $2 \mathrm{ml}$ of $0.9 \%$ saline solution $\left(20^{\circ} \mathrm{C}\right)$ five times. The washings were pooled by litter groups. After the lavages, the lungs were dried in a desiccator at $100^{\circ} \mathrm{C}$ until their weight was constant.

The alveolar washes were stirred with an equal volume of methanol and lipids extracted with two volumes of chloroform (10).

The extracted lipids were plated and run on heat-activated thin layers of silica gel $\mathrm{H}$ containing $5 \%$ ammonium sulphate. The plates were developed using chloroform-methanol-acetic acid$\mathrm{H}_{2} \mathrm{O}(390-150-48-24 \mu / \mu)$.

After development of the chromatograms, the plates were charred at $280^{\circ} \mathrm{C}$ for $10 \mathrm{~min}$ to visualize compounds. Lecithin was eluted, and phosphorus determination was performed by the method of Bartlett (2). The statistical analysis was done by the $t$ test.

\section{RESULTS}

The lecithin phosphorus concentrations in lung washes of both groups are shown in Figure 1. The level of lecithin phosphorus in the lung washes of the fetuses whose mothers received Bromocriptine was $\bar{X}=2.24 \pm 0.39 \mu \mathrm{g} / \mathrm{g}$ dry lung weight, whereas that of fetuses of control does was $\mathrm{X}=6.93 \pm 2.64 \mu \mathrm{g} / \mathrm{g}$ dry lung weight. The difference was statistically significant $(P<0.001)$.

It was also observed that Bromocriptine administration caused a reduction in body weight of the fetuses and in the weight gain of the does (Table 1).

The mean body weight of the fetuses from treated mothers was $38.22 \pm 6.39 \mathrm{~g}$ whereas that of fetuses from control rabbits was $47.63 \pm 6.94 \mathrm{~g}$.

The $t$ test showed that the difference was statistically significant $(P<0.001)$.

The mother body weight gain from days 26 to 30 was significantly lower in the treated animals. The mean body weight gain 
Table 1. Comparison between fetus body weight, mother's body weight at 26 th day of gestation, and weight gain from days 26 to 30 and litter size in treated and control groups

\begin{tabular}{|c|c|c|c|c|c|c|c|}
\hline & \multicolumn{3}{|c|}{ Treated } & \multicolumn{3}{|c|}{ Control } & \\
\hline & $N$ & $\overline{\mathrm{X}}$ & S.D. & $N$ & $\overline{\mathrm{X}}$ & S.D. & \\
\hline Fetal body wt (g) & 62 & 38.22 & 6.39 & 51 & 47.63 & 6.49 & $t=7.46 ; P<0.001$ \\
\hline $\begin{array}{l}\text { Mother's body wt at 26th day } \\
\text { (g) }\end{array}$ & 9 & 3,573 & 526.0 & 8 & 3,706 & 599.0 & $\mathrm{NS}^{1}$ \\
\hline $\begin{array}{l}\text { Mother's body wt gain from } \\
\text { days } 26 \text { to } 30(\mathrm{~g})\end{array}$ & 9 & 156.11 & 99.4 & 8 & 374.38 & 166.21 & $t=3.33 ; P<0.01$ \\
\hline Litter size (no. of fetuses) & 9 & 7.0 & 1.91 & 8 & 6.5 & 1.77 & NS \\
\hline
\end{tabular}

'NS, not significant.

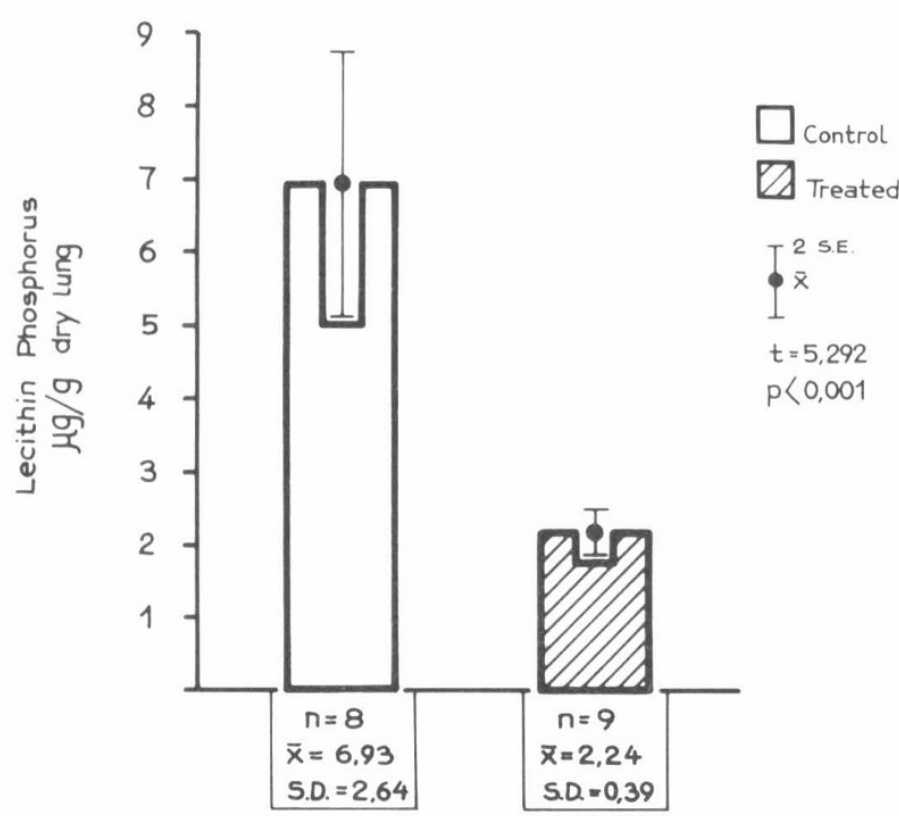

Fig. 1. Lecithin phosphorus concentration in fetal lung washes from control and treated mothers.

in Bromocriptine-treated rabbits was $156.11 \pm 99.4 \mathrm{~g}$ whereas that of controls was $374.38 \pm 166.21 \mathrm{~g}$. The $t$ test showed that this difference was statistically significant $(P<0.01)$.

There were no differences in the does body weight at the 26th day and in the litter size of both groups of animals (Table 1).

\section{DISCUSSION}

Many hormones affect lecithin production by the fetal lung.

There are conflictive reports about the effect of prolactin. Hamosh and Hamosh (14) reported that $1 \mathrm{mg}$ of purified ovine prolactin administered intramuscularly to fetal rabbits on day 24 th of gestation resulted in an increase of $67 \%$ in lung dipalmitoylphosphatidylcholine $48 \mathrm{hr}$ later. This result could not be confirmed by the experiments in rabbits and sheep performed by Ballard et al. (1) using a similar scheme. Also, it was reported that the administration of $1.0 \mathrm{mg}$ intramuscular prolactin on the $24 \mathrm{th}$ day to fetal rabbits did not modify the pressure-volume relationship of the lung analyzed 2 days later (23).

On the other hand, Cox and Torday (6) have shown that the presence of $10 \mu \mathrm{g} / \mathrm{ml}$ of ovine prolactin (Sigma Chemical Co.) in tissue cultures from 28th day fetal rabbit lung cells leads to an increase in lecithin and disaturated lecithin production by these cells. The addition of ovine prolactin $(\mathrm{NIH})$ did not show any effect. Also Porreco et $l$. (20) suggest a stimulation of phosphatidylcholine synthesis in alveolar cell carcinoma monolayer culture by addition of human prolactin.

Clinical studies seem to support the concept that prolactin could be a physiologic inducer of lecithin production by the fetal lung. Several workers $(11,12,15,21,22)$ reported lower levels of cord prolactin in premature newborns that developed respiratory distress syndrome as compared with premature infants that did not develop this syndrome.

In our study, the administration of bromoergocriptine on days 27 to 29 of gestation to pregnant rabbits, was associated with lower lecithin concentration in fetal lung washes performed at the 30 th day of gestation. These results agree with those obtained by Mullon et al. (18).

Although we know that bromoergocriptine could have some vascular effects (9), we assume that these effects could not significantly modify lung lecithin production.

The reduction in lecithin content in lung washes observed after the administration of bromoergocriptine may be related to the inhibition of prolactin release, since in sheep it has been shown that bromoergocriptine could decrease prolactin secretion in the fetus (13).

The weight of the fetuses from treated rabbits was lower than that of the control group; this reduced weight might be partially responsible for the decrease in maternal weight gain of our treated does. Also, it is well known that prolactin is involved in the control of lipid metabolism (17). Therefore, by reducing fat content, this could partially respond for the decreased maternal and fetal weights.

Further observations (i.e., maternal and fetal prolactin levels and fetal adrenal function) are necessary to elucidate the mechanism of action of bromoergocriptine in lecithin production by the fetal lung.

\section{REFERENCES AND NOTES}

1. Ballard, P. L., Gluckman, P. D., Brehier, A., Kitterman, J. A., Kaplan, S. L., Rudolph. A. M., and Grumbach, M. M.: Failure to detect an effect of prolactin on pulmonary surfactant and adrenal steroids in fetal sheep and rabbits. J. Clin. Invest., 62: 879 (1978).

2. Bartlett, G. R.: Phosphorus assay in column chromatography. J. Biol. Chem., 234: 466 (1959).

3. Bustos, R., Ballejo, G., Giussi, G., Rosas, R., and Isa, J. C.: Inhibition of fetal lung maturation by indomethacin in pregnant rabbits. J. Perinat. Med., 6: 240 (1978).

4. Catterton, W. Z., Escobedo, M. B., Sexson, W. R., Gray, M. E., Sundell, H. W., and Stattlman, M. T.: Effect of epidermal growth factor on lung maturation in fetal rabbits. Pediatr. Res., 13: 104 (1979).

5. Corbet, A. J. S., Flax, P., and Rudolph, A. J.: Reduced surface tension in lungs of fetal rabbits injected with pilocarpine. J. Appl. Physiol., 41: 7 (1976).

6. Cox, M. A., and Torday, J. S.: Relative increase in saturated lecithin in prolactin treated fetal lung cultures. Pediatr. Res. (Abstract), 12: 559 (1978).

7. De Lemos, R. A., Shermeta, D. W., Knelson, J. H., Kotas, R., and Avery, M. E.: Acceleration of appearance of pulmonary surfactant in the fetal lamb by administration of corticosteroids. Am. Rev. Respir. Dis., 102: 459 (1970).

8. Farrell, P. M.: Fetal lung development and the influence of glucocorticoids on pulmonary surfactant. J. Steroid Biochem., 8: 463 (1977).

9. Flückiger, E.: The pharmacology of bromocriptine. In: Pharmacological and Clinical Aspects of Bromocriptine (Parlodel). pp. 12-26 (R. I. S. Bayliss, P. Turner, and W. P. Maclay, Publishers, Grange Press, Southwick, Sussex, 1976).

10. Folch, J., Lees, M., and Sloane Stanley, G. H.: A simple method for the isolation and the purification of total lipids from animal tissues. J. Biol. Chem., 226: 497 (1957).

11. Gluckman, P. D., Ballard, P. L., Kaplan, S. L., Liggins, G. C., and Grumbach, M. M.: Prolactin in umbilical cord and the respiratory distress syndrome. J. Pediatr., 93: 1011 (1978).

12. Gluckman, P. D., Ballard, P. L., Kitterman, J. A., Kaplan, S. L., and Grumbach, M. M.: Fetal Prolactin (PRL) and the respiratory distress syndrome (RDS). 
Pediatr. Res, (Abstract), 12: 524 (1978).

13. Gluckman, P. D., Marti-Henneberg, C. Thomsett, M. J., Kaplan, S. L.. Rudolph, A. M., and Grumbach, M. M.: Hormone ontogeny in the ovine fetus. VI. Dopaminergic regulation of prolactin secretion. Endocrinology, 105: 1173 (1979).

14. Hamosh, M. and Hamosh. P. The effect of prolactin on the lecithin content of fetal rabbit lung. J. Clin. Invest., 59: 1002 (1977).

15. Hauth, J. C., Parker, C. R., Jr., MacDonald, P. C., Porter, J. C., and Johnston. J. M.: A role of fetal prolactin in lung maturation. Obstet. Gynecol.. 51:81 (1978).

16. Khosla, S. S., and Rooney, S. A. Stimulation of fetal lung surfactant production by administration of 17-Beta-estradiol to the maternal rabbit. Am. J. Obstet. Gynecol., 133: 213 (1979).

17. Meier, A. H.: Prolactin, the liporegulatory hormone. Adv. Exp. Med. Biol., 80: 153 (1977).

18. Mullon, D. K., Smith, Y. F., Hamosh, M., and Hamosh, P.: Prolactin and fetal lung maturation: effect of bromocryptine administration. Clin. Res., 27: 401 A (1979).

19. Neufeld, N. D., Sevanian, A., Barret, C. T., and Kaplan, S. A.: Inhibition of surfactant production by insulin in fetal rabbit lung slices. Pediatr. Res., 13: 752 (1979).

Copyright (C) 1981 International Pediatric Research Foundation, Inc. $0031-3998 / 81 / 1505-0850 \$ 02.00 / 0$
20. Porreco, R. P., Metritt, T. A., and Gluck, L.: Effect of prolactin on phospholipid biosynthesis by alveolar cell carcinoma (A549) in monolayer tissue culture. Am. J. Obstet. Gynecol., 136: 1071 (1980).

21. Smith, Y. F., Mullon, D. K., Hamosh, M., Scanlon, J. W., and Hamosh, P. Prolactin and human lung maturation. Pediatr. Res. (Abstract), 12: 569 (1978)

22. Smith, Y. F., Mullon, D. K., Hamosh, M., Scanlon, J. W., Hamosh, P.: Serum prolactin and respiratory distress syndrome in the newborn. Pediatr. Res., 14 $93(1980)$

23. Van Petten, G. R., and Bridges, R.: The effects of prolactin on pulmonary maturation in the fetal rabbit. Am. J. Obstet. Gynecol., 134: 711 (1979).

24. Wu, B., Kikkawa, Y. Orzalesi, M. M., Motoyama, E. K., Kaibara, M., Zigas, C. J., and Cook, C. D.: The effect of thyroxine on the maturation of fetal rabbit lungs. Biol. Neonate, 22: 161 (1973)

25. Wyszogrodski, I. Taeusch, H. W. and Avery, M. E.: Isoxsuprine-induced alterations of pulmonary pressure-volume relationships in premature rabbits. Am. J. Obstet. Gynecol., 119: 1107 (1974)

26. Requests for reprints should be addressed to: Dr. Gustavo A. Giussi, Centro Latinoamericano de Perinatologia y Desarrollo Humano, Casilla de Correo 627, Montevideo, Uruguay.

27. Received for publication June 24, 1980.

28. Accepted for publication September 2, 1980 